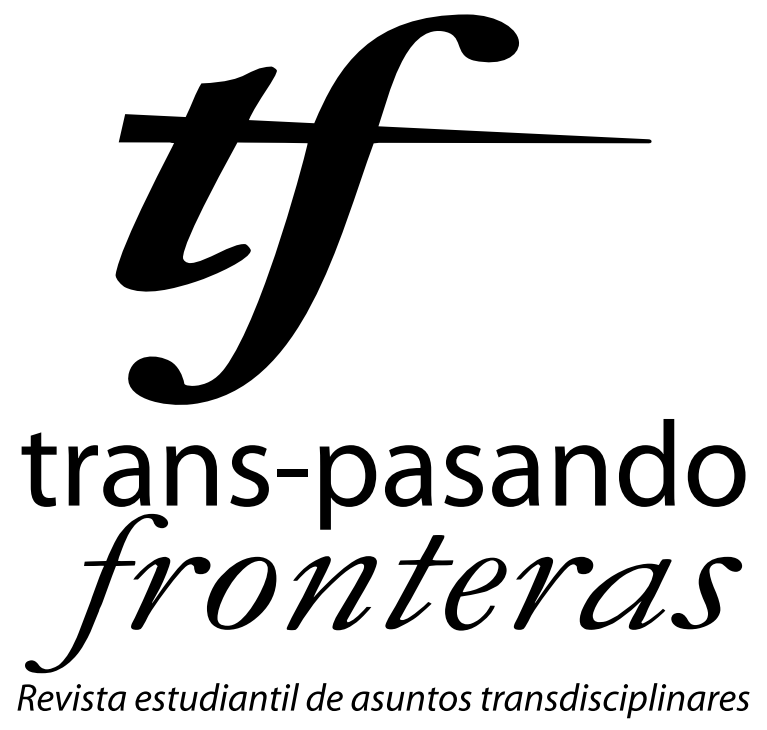

Una publicación de

Facultad de Derecho y Ciencias Sociales

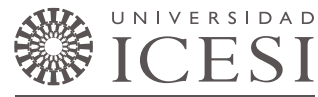




\title{
Global community
}

\author{
Juan D. Montoya \\ (jd_mon@hotmail.com)
}

IRIYE, Akira (2004) Global Community: The Role of International Organizations in the Making of the Contemporary World. University of California Press, 255 páginas.

Born in Tokyo in 1934, Akira Iriye is a Japanese historian who graduated from Haverford College in the United States and was awarded a Ph.D. degree by Harvard University. He is better known in the academic circles as a specialist in American and Asian-American diplomatic history, but he is also the author of "Global community". Professor Akira Iriye's book seeks to examine how global affairs are constantly put in motion not only by nations and international organizations, but by organized people too. This way, the history of globalization and of how it has accelerated is told through the prism of how many and how important international organizations have been, both inter-governmental and non-governmental ones.
Non-governmental organizations can be understood as those organizations that do not have any interest in obtaining profit. With these limitations, most of international organizations (i.e. international businesses) must be putted off the table. Only those that have social, humanitarian or non-profit technological interests are classified as non-governmental organizations for the purpose of Iriye's study.

In today's world, non-governmental organizations are important since they are able to flourish because there are people in one country who are concerned with people's situation in other countries, without national boundaries being a limitation. It is what professor Iriye calls the Global Community emphasizing the fact that international organizations -both in- 
ter-governmental and non-governmentalhave a strong impact on how the world is being shaped today, but it has been so for a longer time that one may think: the term global is used by purpose in order to make a reference to the world that precedes the international community, latter being in existence only since the 17 th century.

As the number of international organizations had been growing -either because of the need to take advantage of shared resources or because of the expansion of some new technologies, the appearance of the distinguishing features of a global community became more evident. The book also makes it clear that there had been moments when it would be more likely to think that international organizations have a limited lifecycle, especially during international crisis. However, most international organizations have survived, and even more impressively, they have continued to be active protagonists on international arena. Even during the times of the global wars, despite of a strong nationalist environment otherwise, organizations that came to life thanks to the internationalist endeavor of their founding fathers and promoters like the Red Cross were very active. The same is true for the times of the Cold War: despite of the dominance of the mostly nation-centric forces, they could not stop the trend towards internationalism and globalization. With the Treaty of Rome, the European Economic Community was established in 1957. Even if it could be regarded as part of the Western strategy to strengthen one side of the equilibrium during the Cold War, it should not be forgotten that it was an initiative which origins can be traces back in the eighteenth century and a result of the global forces that have longer cycles in history.

When the world seems to be more divided, there are always some actions that are the result of global forces that tend to overcome the power of single nations, even if it is a nationalist movement attempting to create a new sovereign state, or it is a people's protest against the government's action. As the book under review demonstrates, the end of the Cold War and the progress of communications made things easier to those who wanted to create an international organization. Today more than ever, people are interested in what is happening around the world, and are willing to participate more in global affairs.

One of particular features of the book 
Global Community is that it shows how international organizations have been growing during a long time, first slowly and nowadays more rapidly, because of the need for recognition of the rules in a world that has being dividing into nations only for a comparatively short period of time. International organizations, even if they are inter-governmental or non-governmental, put pressure on the governments in order to make them behave in more acceptable ways.

Reading the book written by Akira Iriye is like watching how societies grow, how they stop being aggressive and start to cooperate, how they accept new rules, even though it may take a longer time to eventually accept them. The book is also about the expansion of societies beyond national borders not because of some kind of business interests but because of knowing that there are common civil interests.

Take, for instant, the issue of human rights. For many years now, the human rights have been considered an important guideline, but they were also often ignored in the past. However, their acceptance has grown and spread all over the world, not lastly because international organizations -that have also grown in number- put pressure on the governments to embrace human rights. Cooperation in technological advances, from the telegraph to the World Wide Web, cannot be achieved just by the governments, without the participation of millions of people across the globe.

The book helps to understand better how the lack of international institutions has made it hard to keep peace and cooperation between nations throughout history. It is also possible to see that we are living in times of transition, when the international institutions have being obtaining much more legitimacy then even in the recent past and when they started to work hand by hand with the governments. It is time for us to keep an eye on how the tendencies towards a wider globalization shape our world and the way we behave, beyond the purely economic aspects. "Global Community" is the book that, without doubts, helps to understand this process better. 